\title{
ENTOMOLOGISTS AND INSECTS IN THE WORLD MEDALLIC ART
}

\author{
Barshteyn V. Yu.
}

\section{INTRODUCTION}

The Auxiliary Sciences of History (Special Historical Disciplines (SHD) in Ukraine) are scholarly disciplines which help evaluate and use historical sources and are seen as auxiliary for historical research ${ }^{1}$. SHD which study certain types of sources (numismatics, bonistics, phaleristics, philately, etc.), more precisely, the objects studied by these disciplines (table or art medals, commemorative coins from the moment of their appearance, paper banknotes and philatelic production), have been increased their informativeness and got in recent decades new function ${ }^{2}$. This function, which has not yet been formulated quite clearly and unequivocally by experts, is to be a historical material source (or a manual) for studying history of: sciences (biology, medicine, physics, chemistry, etc.), types of art (painting, music, sculpture, architecture, etc.), geography, politics, etc. We mean that using information which has contained by medals, coins, banknotes, stamps, postal blocks and other material sources, one can study history, for example, the history of entomology $\mathrm{y}^{3,4}$.

Among SHD sources devoted to entomology majority are the objects of philately, which is natural, given their large circulations issued by most countries of the world ${ }^{5,6,7,8,9,10}$. It should be noted that the vast majority of stamps are not dedicated to entomologists, but insects.

At the same time, numerous table medals belonging to the SHD sources are dedicated to the entomologists. There are some publications about one or

\footnotetext{
Спеціальні історичні дисципліни: довідник: навч. посіб. для студ. вищ. навч. закл. / Войцехівська І.Н. (кер. авт. кол.), Томазов, В.В., Дмитрієнко М.Ф. та ін. К.: Либідь, 2008. 520 с.

2 Барштейн В.Ю. Новая функция специальных исторических дисциплин. Maтериаль международной заочной научной конференции «Исторические исследования». Уфа. 2012. С. $76-79$.

${ }^{3}$ Essig E.O. A History of Entomology. Hafner Publishing Company, 1965. 1029 p.

${ }^{4}$ Smith E.H., Kennedy G.G. Chapter 119 - History of Entomology. In: Encyclopedia of Insects (Second Edition). 2009, P. 449-458.

${ }^{5}$ Smith M.E. Philatelic Lepidoptera: 1954-1957. The Lepidopterists' News. 1957. № 11(6). P. 221-224.

${ }^{6}$ Hessel S.A. A Taxonomic list of philatelic Lepidoptera. Journal of the Lepidopterists' Society. 1968. Vol. 22, no. 4. P. 241-252.

${ }^{7}$ Hamel D.R. Insects on stamps. American Entomologist. Winter 1990. P. 273-281.

${ }^{8}$ Pruess K.P. Postage Stamps Showing Bees and Hives. Bee World. 2015. P. 53-56.

${ }^{9}$ Gomez B. \& Junghans C. Los alacranes (Arachnida: Scorpionida) en la filatelia. Scorpions (Arachnida: Scorpionida) in postal stamps. Dugesiana. 2016. № 23(1). P. 37-43.

${ }^{10}$ Kabourek K. Beetles on stamps. Ethnoentomology. 2017. № 1. P. 52-72.
} 
another entomologist ${ }^{11,12,13}$. However, as far as we know, there are very few special publications about entomologists in medallic art.

Both general scientific (historical, logical) and special (subjectchronological, retrospective) methods were used in the work.

\section{Entomologists and objects of their research on art medals}

The portrait of Pierre André Latreille (1762-1833) and the image of Necrobia ruficollis Fabricius, redshouldered ham beetle, a mostly carnivorous beetle in the family Cleridae, are on the obverse (fig. 1) of the franch medal (ø $77 \mathrm{~mm}$, bronze, author - Emile Renard, 1982). As believe, Latreille owes life to this beetle. The Roman Catholic priest, he was imprisoned during the French Revolution and, refusing to swear under the Civil Constitution of the Clergy, was to be executed. He gained freedom only after he recognized the rare aforementioned beetle that he found in prison. Latreille actively participated in the creation of Société entomologique de France (reverse of the medal, fig. 2), and was its Honorary President. He was considered the foremost entomologist of his time, and was described by one of his pupils as "the prince of entomologists"

Second medal (ø 31.1, silver, author - Lea Ahlborn, Sweden, 1855) dedicated to the Carl Fredrik Fallén (1764-1830), a Swedish botanist and entomologist (fig. 3) who described many species of Diptera and Hymenoptera. The representative of the order Hymenoptera is on the reverse. Fallén was a member of the Royal Swedish Academy of Sciences from 1810. The author of 81 scientific publications, he was the most famous entomologist in Lund at his time, and it can be considered that he founded entomological collections there.

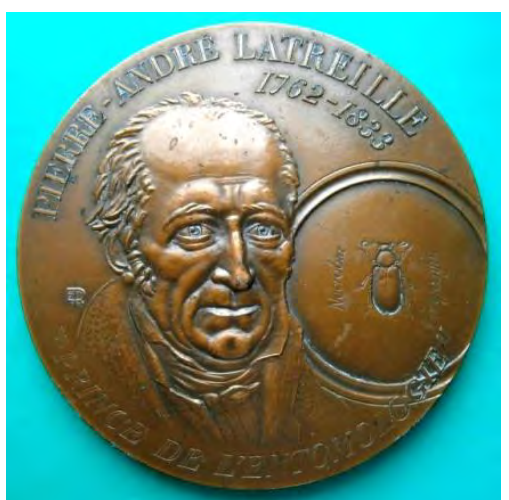

Fig. 1. P.A. Latreille medal, obverse Fig. 2. P.A. Latreille medal, reverse

\footnotetext{
${ }^{11}$ Lhoste J. Les insectes et les medailles de la Monnaie de Paris. Insectes. 1988. 69(2). P. 16-19.

12 Блюм Я., Барштейн В. Ювілей Чарльза Дарвіна в медальєрному мистецтві. Вісник Наџіональної академії наук України. 2009. № 2. С. 51-55.

${ }^{13}$ Барштейн В.Ю. Карл Лінней, його внесок у біологічну науку в медальєрному мистецтві. Наукові звписки Тернопільського національного педагогічного університету імені Володимира Гнатюка. Серія: біологія. 2011. № 3(48). С. 143-150.

${ }^{14}$ Dupuis C. Pierre Andre Latreille (1762-1833): The Foremost Entomologist of his Time. Annual Review of Entomology. 1974. 19(1): 1-14. doi:10.1146/annurev.en.19.010174.000245.
} 


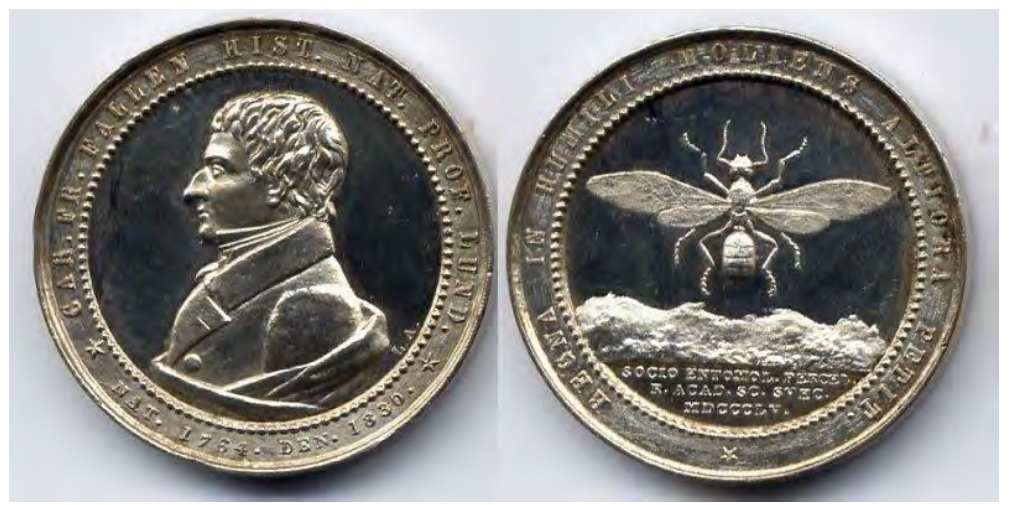

Fig. 3. Carl Fredrik Fallén medal (obverse and reverse)

Probably the largest number of table medals and plaques is devoted to Jean-Henri Casimir Fabre (1823-1915) - a French naturalist, entomologist, and writer known for his exciting popular books about the life of insects.

On a 1910 plaque $(70,5 \times 54,5 \mathrm{~mm}$, bronze, author - F. Sicard, France), along with a profile portrait on the obverse (fig. 4), on the reverse (fig. 5) is given the name of a 10-volume work which Fabre wrote for almost 30 years "Souvenirs Entomologiques". His "Souvenirs Entomologiques" is a series of texts on insects and arachnids. In the upper part of the reverse, the sculptor depicted insects, among which the Mantis religiosa beloved by Fabre.
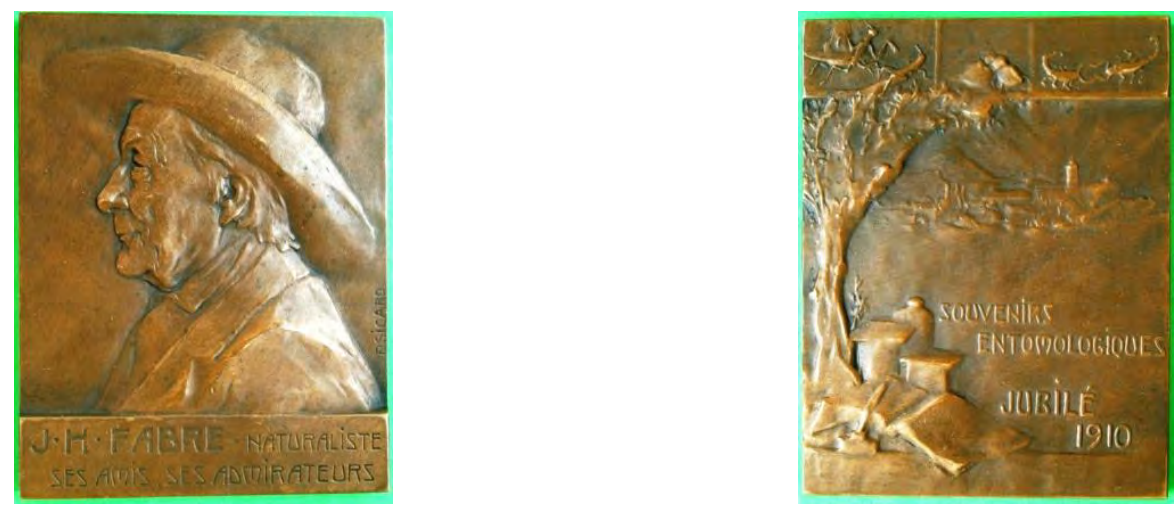

Fig. 4. Fabre plaque 1910 (obverse) Fig. 5. Fabre plaque 1910 (reverse)

"Souvenirs Entomologiques" influenced the later works of Charles Darwin, who called Fabre "an inimitable observer". It should be noted that Fabre was skeptical of Darwin's theory of evolution. Fabre preferred accurate and detailed observation, field research, avoided general conclusions from his observations, always refrained from all theories and systems ${ }^{15}$.

In the next 1911, the sculptor L. Patriarche created another highly artistic plaque $(70,5 \times 50,5 \mathrm{~mm}$, bronze, France) in honor of Fabre with images of insects on both the obverse (fig. 6) and reverse (fig. 7). The obverse also

\footnotetext{
15 Гиляров М.С. Жан Анри Фабр. К 150-летию со дня рождения. Энтомологическое обозрение. 1974. т. 53, № 1 .
} 
depicts the scientist himself, engaged in his favorite work, which, as we indicated above, he valued most of all - observing the life of insects.
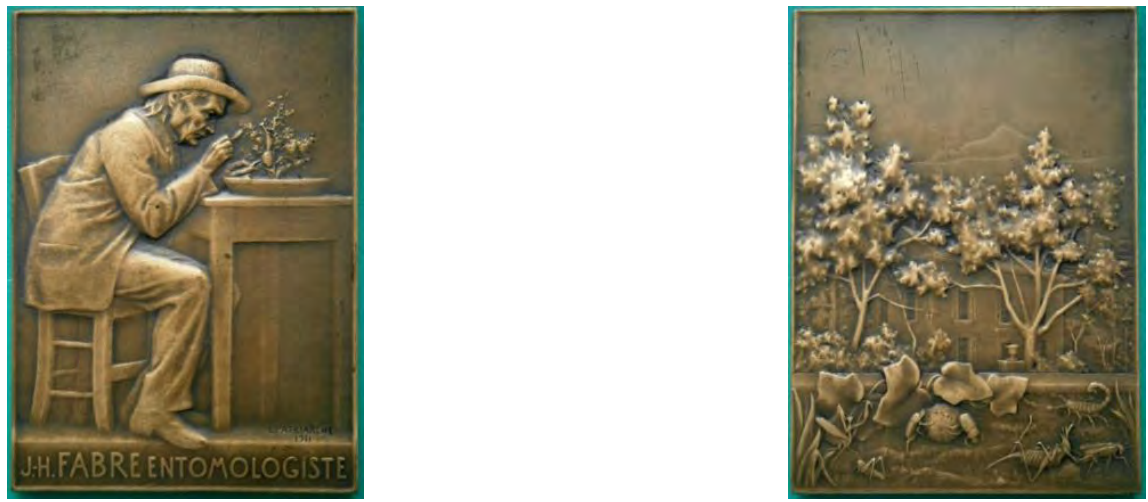

\section{Fig. 6. Fabre plaque 1911 (obverse) Fig. 7. Fabre plaque 1911 (reverse)}

Artwork of the Czech sculptor E. Hlavica devoted to Antonin Fleischer (Fleisher on the obverse (fig. 8), 1850-1934) a Czech physician and entomologist who specialized in Coleopterology. He began his medical practice 1875 in Brno. In 1878 he was the military doctor and after 1880 - a private physician. Fleischer was interested in beetles from a young age. During his studies, he helped in working with zoological collections of the National Museum (Prague). He became a recognized expert. In 1873 he took part in the preparation of the entomological exposition for the World's Fair in Vienna. He has authored several scientific publications and a catalog of Coleoptera $^{16}$. His comprehensive knowledge can probably be explained by the inscription on the reverse (fig. 9) of the medal (ø $50 \mathrm{~mm}$, bronze, 1925). The image of a stag beetle (family Lucanidae) is surrounded by an inscription in Czech, which can be translated: "Nestor of the Czechoslovak entomology". His collection of nearly 30.000 specimens including the types of species described by him were purchased by the National Museum in 1935 .

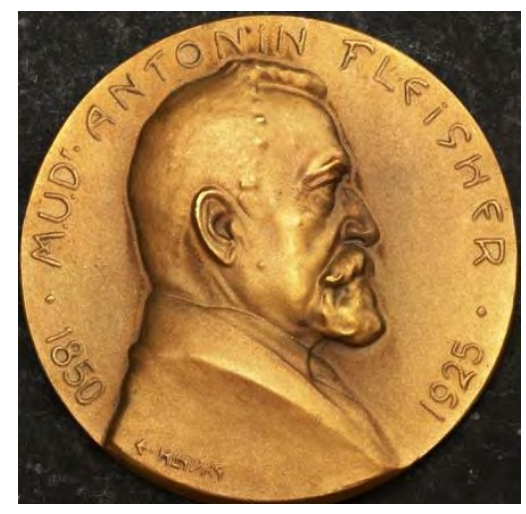

Fig. 8. Fleischer medal (obverse)

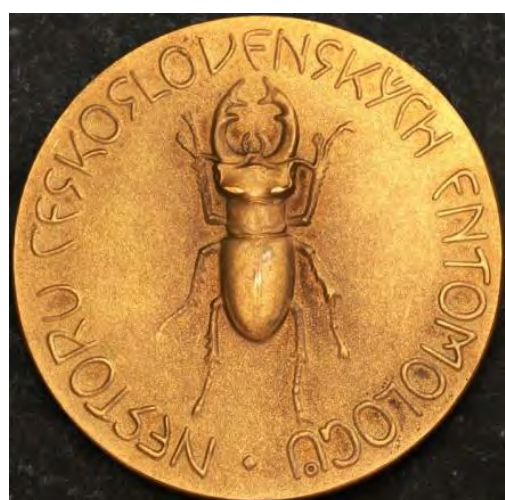

Fig. 9. Fleischer medal (reverse)

\footnotetext{
${ }^{16}$ Koleška Zdeněk. "Fleischer Antonín”. Biografický slovník. 2014. Volume 17. P. 257-258.
} 
The portrait of Mario Bezzi (1868-1927) - an Italian Doctor of Science, professor of zoology at the University of Turin, director of the Turin Museum of Natural History surrounds the inscription (MARIUS BEZZI DIPTEROLOGIAE PRINCEPS) on the obverse (fig. 10) of the Italian medal (ø $60 \mathrm{~mm}$, bronze, author - G. Masoero, 1960). The representative of the order Diptera - on the reverse (fig. 11) of the medal. Both the inscription and the image are not random. Bezzi was a great specialist in the systematics of Diptera. He developed the famous theory of the evolution of wings in Diptera and the formation of new taxonomic entities as a result of the influence of the conditions of their habitats at different altitudes.

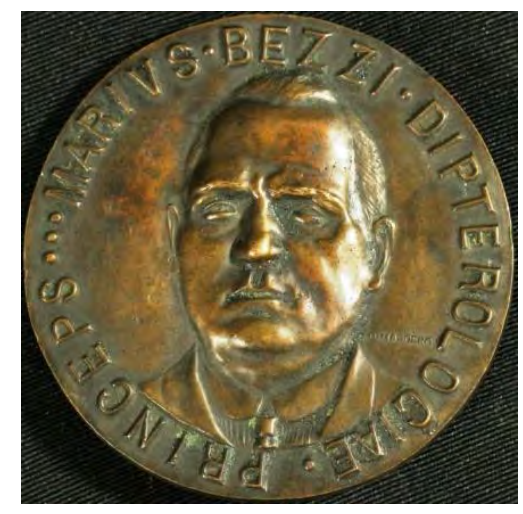

Fig. 10. Bezzi medal (obverse)

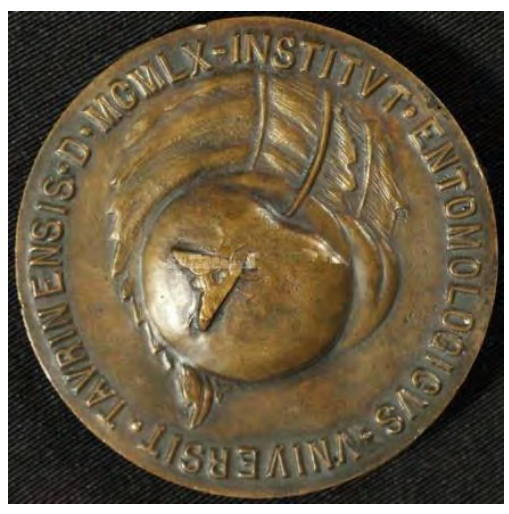

Fig. 11. Bezzi medal (reverse)

It should be noted that for many years he was a professor of natural sciences in school and went to fame for a long time. With more than two hundred publications, participation in conferences, Bezzi has gained international fame and a reputation as one of the greatest zoologists of his time.

Finnish medallic art is represented by two medals.

G. Qvist is the author of the medal (ø $56 \mathrm{~mm}$, bronze, Finland, 1949) to the 70th anniversary of the Harry Federley (1879-1951) - the greatest Finnish geneticist and cytologist, the founder of the Finnish genetics, and one of the founders of modern cytogenetics (fig. 12). Federley's scientific work started in mycology, but he soon turned to the Lepidoptera as material for his investigations. He was an excellent ecologist and taxonomist of this group, and besides his genetical and cytological work, he published numerous papers on all phases of the biology of the Lepidoptera. Most of his papers, however, dealt with the chromosomes of Lepidoptera and with hybridization in this group $^{17}$. This is illustrated by the reverse of the medal (fig. 13).

\footnotetext{
17 Goldschmidt R.B. Harry Federley: 1879-1951. Science. 1952. Volume 115. P. 561-562. doi: 10.1126/science.115.2995.561-a.
} 


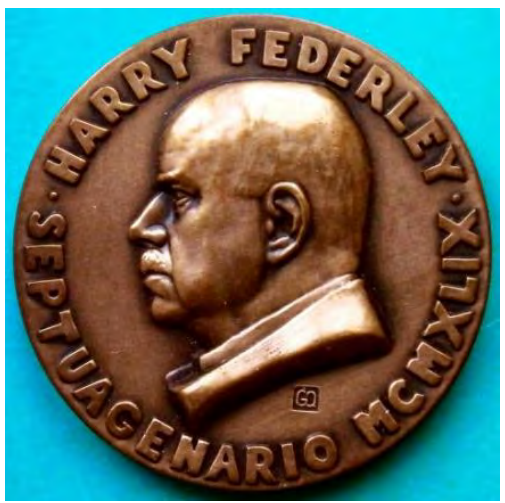

Fig. 12. Federley medal (obverse)

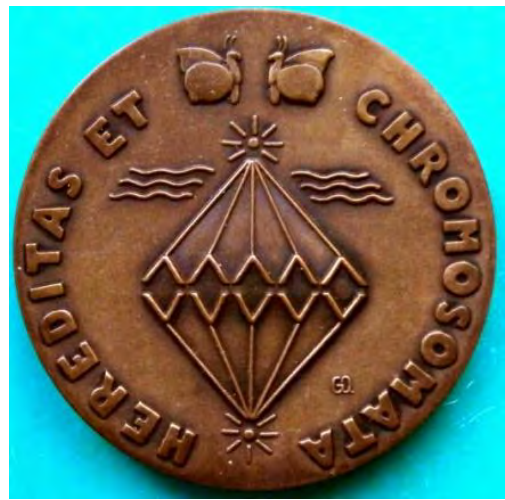

Fig. 13. Federley medal (reverse)

Second Finnish medal ( $\varnothing 70 \mathrm{~mm}$, bronze, 1980) by T. Sakki also devoted to the geneticist and lepidopterist Professor Esko Suomalainen (fig. 14), who had a long career as a lepidopterist: he published an article about an insect migration in the year 1935 and about the lepidopterous fauna in 1979. Throughout his scientific career, Professor Suomalainen was a geneticist. He dealt mainly with the parthenogenesis of beetles and other insects, and with the polymorphism and chromosomes of Lepidoptera. And in this case also, the sculptor demonstrated the scientific preferences of the scientist by reverse of the medal (fig. 15). Suomalainen was the first president of the Finnish Lepidopterological Society from 1955 to $1979^{18}$.

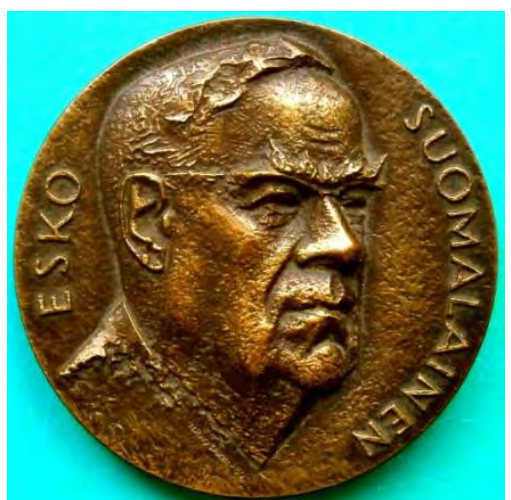

Fig. 14. Suomalainen medal (obverse)

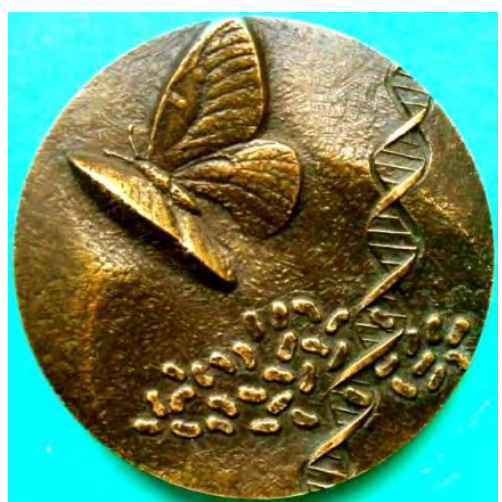

Fig. 15. Suomalainen medal (reverse)

The next medal is dedicated to the Germaine Cousin (1896-1992) (obverse fig. 16) - famous French specialist in crickets (depicted on the reverse of the medal, fig. 17). Mademoiselle Cousin was the Professor of Sorbonne University, Head of the Laboratory of General and Applied Entomology of the Museum, and President of the Société entomologique de France (1963).

\footnotetext{
${ }^{18}$ Mikkola Kauri. Biography of Prof. Esko Suomalainen, Honorary member of SEL. Notalepid. 1987. Volume 10(2). P. 113-114.
} 


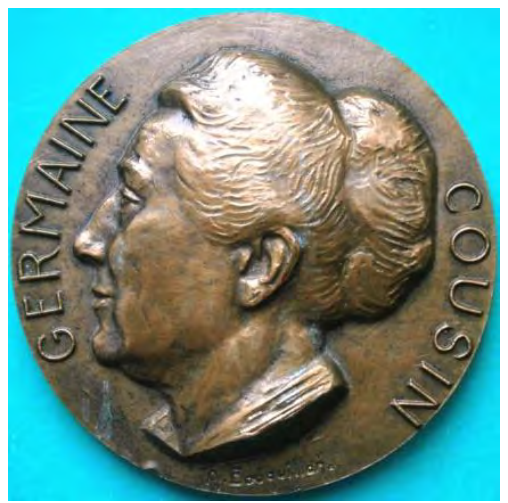

Fig. 16. Cousin medal (obverse)

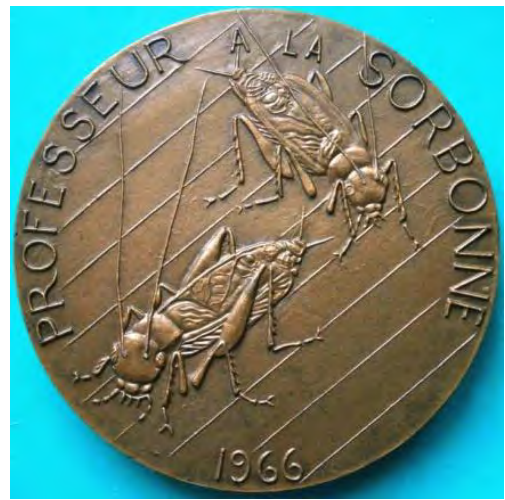

Fig. 17. Cousin medal (reverse)

In 1993 she bequeathed by will to the Société entomologique de France, a sum intended to award scholarships and prizes to amateur researchers or professionals, in pure or applied entomology. The medal (ø $58 \mathrm{~mm}$, bronze, France) was created by the sculptor A. Bouquillon in 1966 to the 70th anniversary of the scientist, whose portrait is located on the obverse.

\section{Physicians, entomologists, insects, diseases}

We took to this section only biologists and doctors, whose struggle with the diseases has been associated with insects that are their carriers.

Louis-Daniel Beauperthuy (1807-1871) was a French-Venezuelan physician who made pioneering observations about the causes of infectious diseases such as yellow fever, malaria, and leprosy. In 1853, a yellow fever epidemic occurred in his hometown of Cumaná, and he observed that the disease seemed to be spread by mosquitoes. He was the first to systematically argue that malaria and yellow fever were transmitted by mosquitoes.

In 1900 the Yellow Fever Commission (YFC) demonstrated that mosquitoes spread yellow fever. This commission was directed by Walter Reed and included Aristide Agramonte, James Carroll and J. William Lazear. Other co-operators were William C. Gorgas and Carlos Finlay. It was Finlay who, in 1881 in Cuba, where the YFC carried out its experiments, had suggested that mosquitoes were the carriers of the disease. This was a theory without experimental proof, a theory to explain the severe epidemics that from time to time afflicted the American Continent. A few years after YFC official report, Agramonte, in 1908 and in 1915 recognized that Louis Daniel Beauperthuy had linked mosquitoes as the carriers of infectious diseases including malaria and yellow fever almost 50 years before the experimental confirmation was carried out by the $\mathrm{YFC}^{19}$.

\footnotetext{
${ }^{19}$ Godoy G.A., Tarradath E. Short biography of Louis Daniel Beauperthuy (1807-71): pioneer of microbiology and medical science in Venezuela. Journal of Medical Biography. 2010. Volume 18. P. 38-40. DOI: $10.1258 / \mathrm{jmb} .2009 .009095$.
} 
French sculptor P. Dupont in 1978 created a medal (ø $68 \mathrm{~mm}$, bronze, France) in honor of Louis-Daniel Beauperthuy. A scientist with a microscope on the background of the Venezuelan landscape - on the obverse (fig. 18) of the medal, a mosquito on the background of the map of Venezuela - on the reverse (fig. 19).

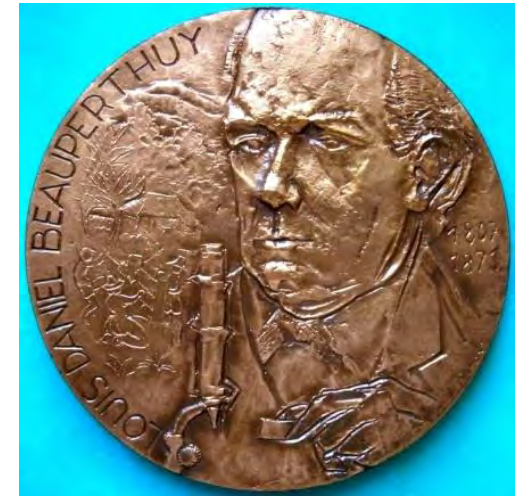

Fig. 18. Beauperthuy medal (obverse)

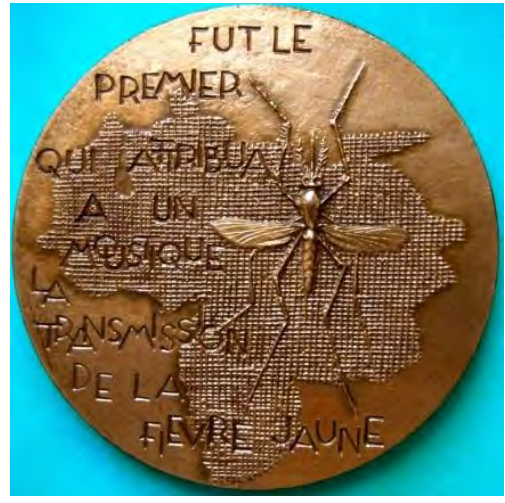

Fig. 19. Beauperthuy medal (reverse)

Several USA medals are dedicated to the members mentioned above YFC. Most medals are dedicated to the YFC leader Major Walter Reed, M.D., U.S. Army (1851 - 1902). One of them - the medal (ø $44 \mathrm{~mm}$, bronze, author - A. Belskie, USA, 1963) from the Hall of Fame For Great Americans series associated with New York University. The portrait of Reed - on the obverse of the medal (fig. 20), and mosquito belonging to the Aedes or Haemogogus species - on the reverse (fig. 21).

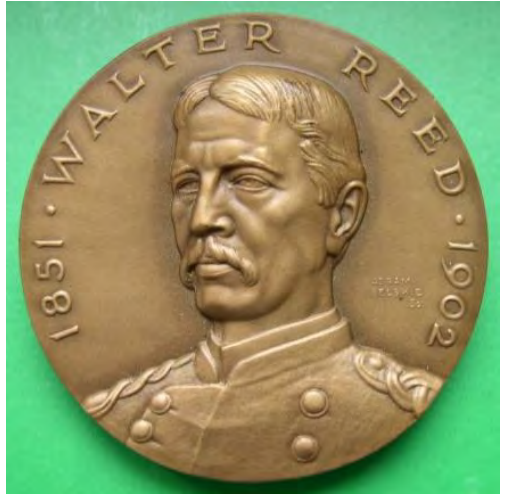

Fig. 20. Reed medal (obverse)

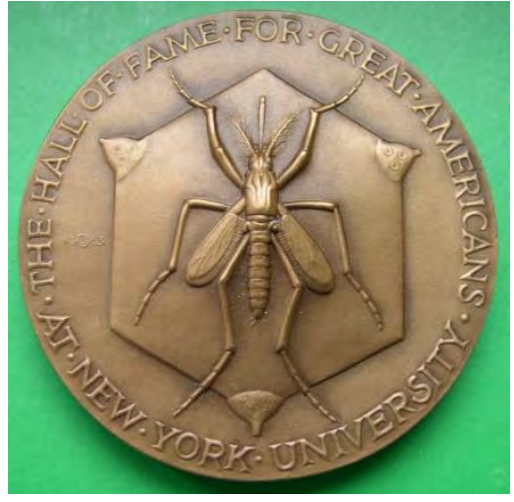

Fig. 21. Reed medal (reverse)

Among the medals dedicated to Reed is the Congressional Gold Medal. The Congressional Gold Medal (ø $50 \mathrm{~mm}$ ) was awarded by Congress on February 28, 1929 (Public Law 70-858, 45 Stat. 1409) to each of the fighters with yellow fever, "in special recognition of the high public service rendered and disabilities contracted in the interest of humanity and science as voluntary 
subjects for the experimentations during the yellow-fever investigations in Cuba".

Among them was Aristide Agramonte (fig. 22).
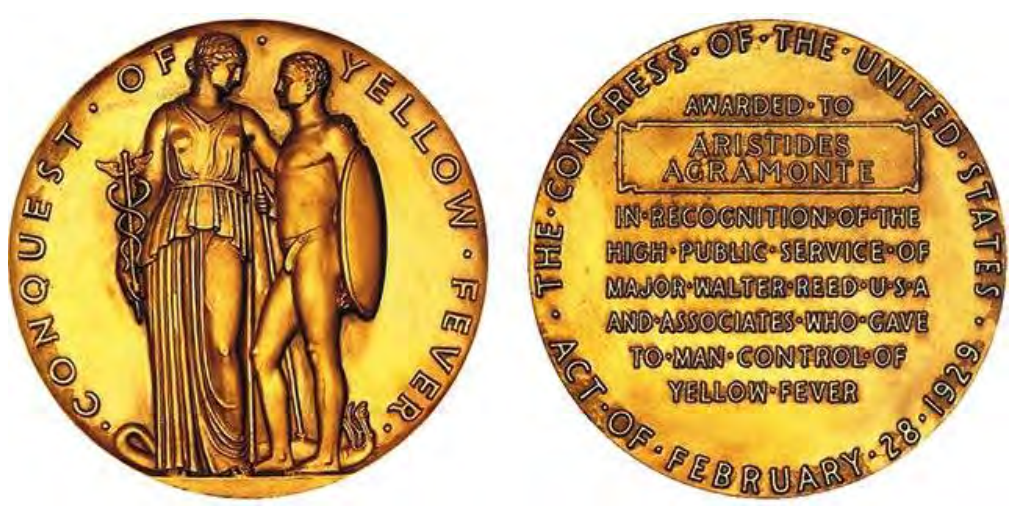

Fig. 22. Agramonte Congressional Gold Medal

Another medal (ø $44 \mathrm{~mm}$, bronze, USA, 1959) from the series "The Hall of Fame of the New York University For Great Americans" created by the sculptor Belsky in honor of William Crawford Gorgas KCMG (1854-1920) - a United States Army physician and 22nd Surgeon General of the U.S. Army (1914-1918). The portrait of Gorgas - on the obverse of the medal (fig. 23), to the right of which is an image of a mosquito. The reverse illustrates an episode of the struggle in Panama against the spread of mosquitoes, led Gorgas (fig. 24).

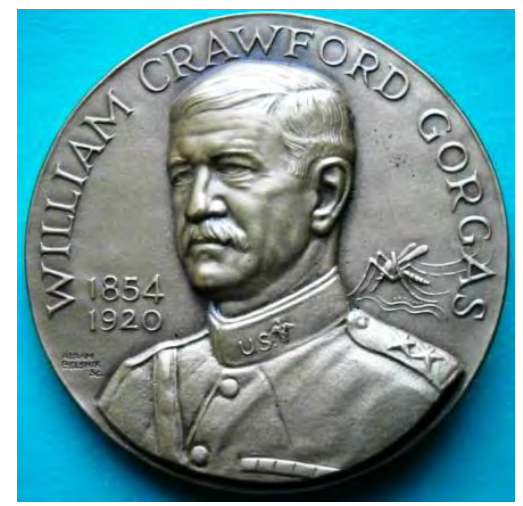

Fig. 23. Gorgas medal (obverse)

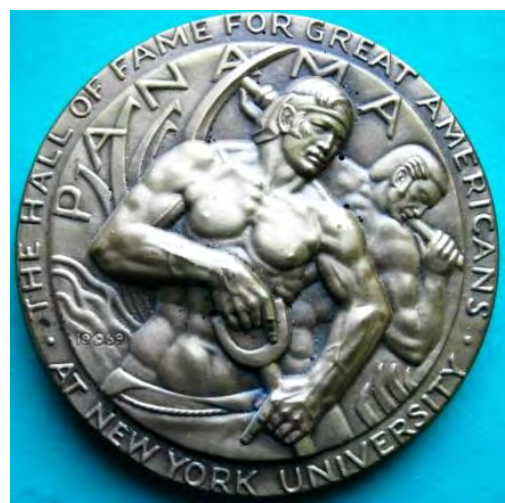

Fig. 24. Gorgas medal (reverse)

William Crawford Gorgas is best known for his work in Florida, Havana and at the Panama Canal in abating the transmission of yellow fever and malaria by controlling the mosquitoes that carry them at a time when there was considerable skepticism and opposition to such measures.

In 1902 President Roosevelt, on the advice of Dr. William Welch, appointed Gorgas as the Chief of Sanitation of the Panama Canal Project. 
Gorgas studied the successful French construction of the Suez Canal and their failure to build the Panama Canal. A quarter of the French workforce died during the implementation of the Panama Project, and one third of employees missed work every day due to illness. Over 22,000 builders died of an infectious disease during a French attempt. Gorgas came to the conclusion that only control over malaria and yellow fever (i.e. the fight against the spread of mosquitoes) will allow him to complete the construction of the Panama Canal ${ }^{20,21}$.

If we are talking about malaria, we can not forget Giovanni Battista Grassi (1854-1925) - an Italian physician and zoologist, best known for his pioneering works on parasitology, especially on malariology. Grassi was especially attracted by Protozoology the field of parasitology. His work ranged from the intestinal protozoa and flagellates of termites to the study of malaria plasmodia. During his research on the transmission of malaria, which Grassi started with a detailed study of hematophagous Diptera in malarial and nonmalarial zones, he became interested in Tabanidae, Simuliidae, Ceratopogonidae, and Phlebotomus.

He was the first to describe and establish the life cycle of the human malarial parasite, Plasmodium falciparum, and discovered that only female anopheline mosquitoes are capable of transmitting the disease. Grassi demonstrated the complete route of transmission of human Plasmodium, and correctly identified the types of malarial parasite as well as the mosquito vector, Anopheles claviger, but 1902 Nobel Prize in Physiology and Medicine was given the British army surgeon Ronald Ross, who discovered the transmission of malarial parasite in birds ${ }^{22}$.

As far as we know the only image of Grassy is on the art medal belongs to the Italian sculptor G. Merlini (ø $75.2 \mathrm{~mm}$, bronze, Italy, 1983). In the center of the obverse (fig. 25) of the medal of the Italian Society of Microbiologists - three portraits of outstanding scientists (from left to right): Girolamo Fracastoro (1476/8 -1553), Lazzaro Spallanzani (1729-1799), and Giovanni Battista Grassi. On the reverse (fig. 26) - the date of the congress of microbiologists in Brescia (Italy).

The next medal (ø $68 \mathrm{~mm}$, bronze, author - H. Dropsy, France, 1957) with portrait (fig. 27) of Émile Roubaud (1882-1962) - a French biologist and entomologist known for his work on paludism, yellow fever and sleeping sickness $^{23}$, attracts attention with the image on the reverse (fig. 28) - very finely executed in detail Glossina palpalis (tsetse, sometimes spelled tzetze

\footnotetext{
${ }^{20}$ Cashman T.M. William Crawford Gorgas. He Set the Standard of Military Preventive Medicine. Hawaii Medical Journal. 1998. Volume 57. P. 377-380.

${ }^{21}$ Craddock W.L. The Achievements of William Crawford Gorgas. Military Medicine. 1997. Volume 162(5). P. 325-327.

${ }^{22}$ Neghme A. An Appraisal of Giovan Battista Grassi: His Work in Biology and Parasitology. Experimental Parasitology. 1964. 15: 260-278.

${ }^{23}$ Emile Roubaud (1882-1962). URL: http://www.pasteur.fr/infosci/archives/f-bio.html.
} 
and also known as tik-tik flies, large biting flies that inhabit much of tropical Africa). Roubaud is studying the transmission of trypanosomiasis and the specific role of tsetse flies. The first, it recognizes the multiplication of polymorphic trypanosomes (T. brucei and T. gambiense) in the fluid of the salivary glands of Glossina palpalis. He proposed methods of combat tsetse. 1914-1958 Roubaud founded and directed a research laboratory for medical entomology and parasite biology at the Pasteur Institut. He teaches medical entomology.

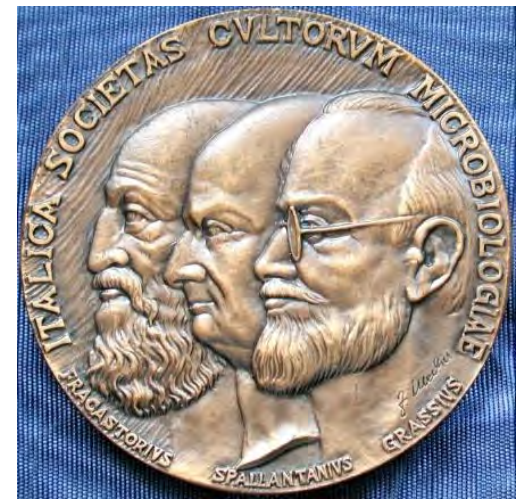

Fig. 25. Grassi medal (obverse)

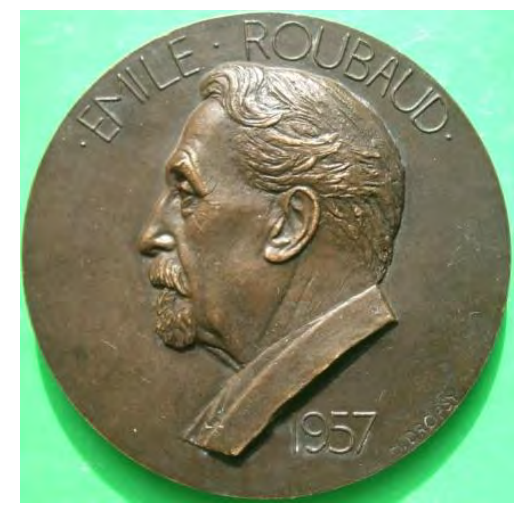

Fig. 27. Roubaud medal (obverse)

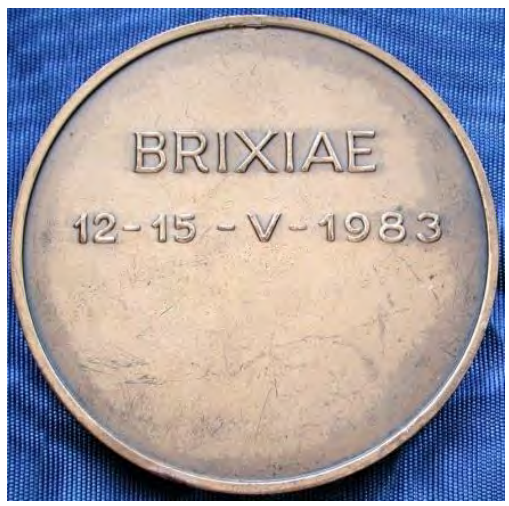

Fig. 26. Grassi medal (reverse)

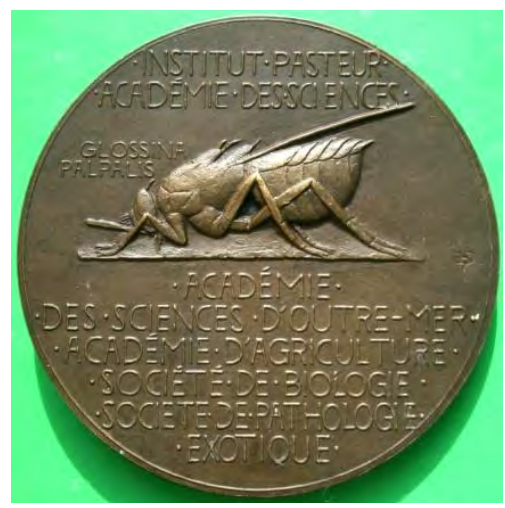

Fig. 28. Roubaud medal (reverse)

\section{Entomologists famous in other fields of activity}

Jean Charles Emmanuel Nodier (1780-1844) was an influential French author, librarian and entomologist who introduced a younger generation of Romanticists to the conte fantastique, gothic literature, and vampire tales ${ }^{24}$.

Among the entomological works of Nodier: "Dissertation sur l'Usage des Antennes dans les Insectes" (1798) - ("A Dissertation on the Use of Antennae in Insects"), "Bibliographie Entomologique" (1801) - ("Entomological Bibliography”).

\footnotetext{
${ }^{24}$ Loving M. Charles Nodier: The Romantic Librarian. Libraries \& Culture. Vol. 38, No. 2. P. 166-181.
} 
Nodier is dedicated the medal (ø $67 \mathrm{~mm}$, bronze, author - C. Corbin, France, 1970), on the obverse (fig. 29) of which is a portrait surrounded by an inscription: "HOMMAGE A CHARLES NODIER. MCMXXXXIV". Reverse (fig. 30) - two women sitting on a low wall braiding a laurel wreath surrounded by an inscription: "1780-1844 BIBLIOTHECAIRE DV ROI. MEMBRE DE L'ACADEMIE FRANÇAISE”.

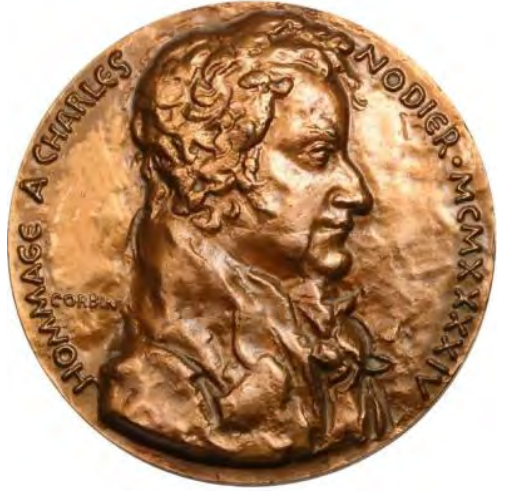

Fig. 29. Nodier medal (obverse)

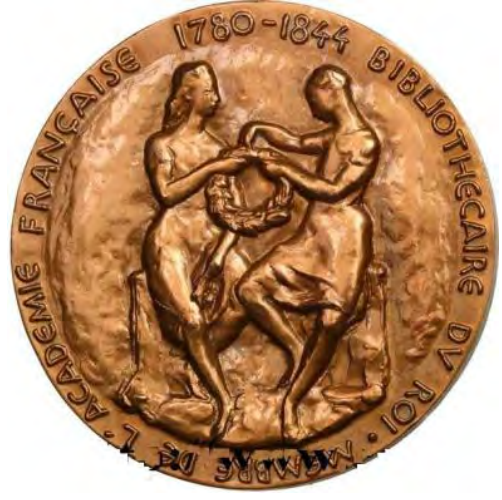

Fig. 30. Nodier medal (reverse)

The next medal (ø $78 \mathrm{~mm}$, former USSR) is also dedicated to the writer 19th-century Russian literary figure Sergey Timofeyevich Aksakov (1791-1859). He was well known for his semi-autobiographical tales of family life, which he published in the late 1850s: "The Family Chronicle" ("Semeinaya khronika", 1856; translated as "A Russian Gentleman") and "Childhood Years of Bagrov Grandson" ("Detskie gody Bagrova-vnuka", 1858, translated as "Years of Childhood"). His fairy tale "The Scarlet Flower" was adapted into an animated feature film in the USSR in 1952. He was also the author of books on hunting and fishing and, of particular interest to us, "Collecting Butterflies" ("Sobiranie babochek", 1858).

Portrait of the writer is on the obverse (fig. 31) and the image of his estate on the reverse (fig. 32).

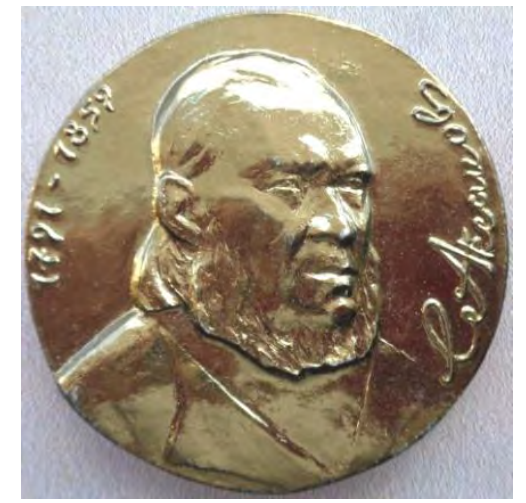

Fig. 31. Aksakov medal (obverse)

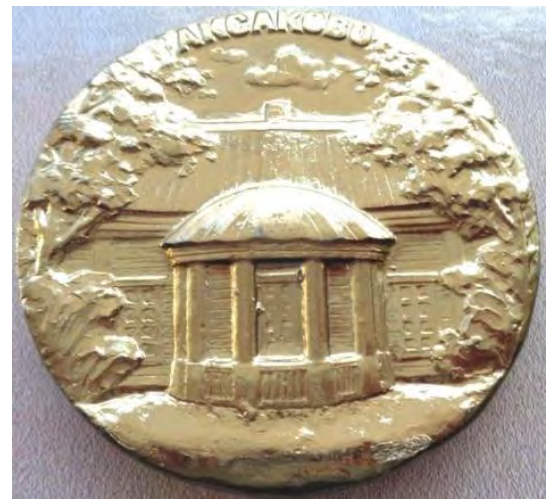

Fig. 32. Aksakov medal (reverse) 
In his youth, an outstanding Russian chemist Alexander Mikhaylovich Butlerov (1828-1886) considered chemistry to be entertainment, and botany, zoology, and especially its division, entomology, were a serious occupation. From childhood, he collected plants, butterflies. At the final stage of training in Kazan University, Butlerov, like all students, to get a candidate degree, was to submit a dissertation (in the modern sense - thesis). Insofar as Alexander was without a scientific adviser, he returned to his hobby - entomology. For his thesis Butlerov prepared an article "Day time Butterflies of Volgo-Ural fauna".

Over time, he became interested in chemistry, became one of the principal creators of the theory of chemical structure (1857-1861), the first to incorporate double bonds into structural formulas, the discoverer of hexamine (1859), formaldehyde (1859), and the discoverer of the formose reaction (1861).

Through all the life Butlerov carried another passion - beekeeping. With his book "The Bee, Her life and the rules of intelligent beekeeping " Butlerov was almost proud more than scientific works. He not only loved bees, but was the largest expert in this matter ${ }^{25}$.

The medal (ø $60 \mathrm{~mm}$, tompak, author - M. Manizer, 1961), on the obverse of which is a portrait of Butlerov (fig. 33), is dedicated to the 100th anniversary of the theory of the chemical structure of substances (fig. 34).

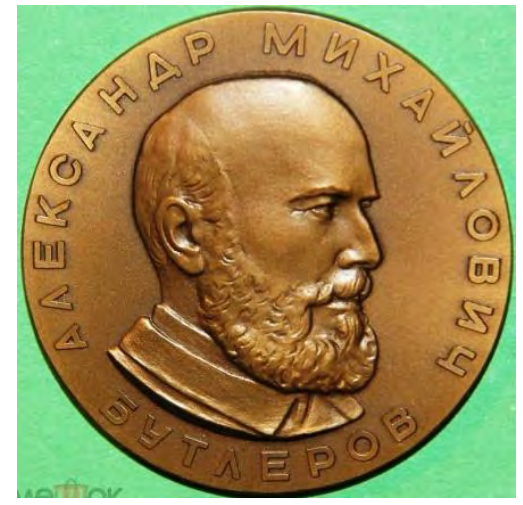

Fig. 33. Butlerov medal (obverse)

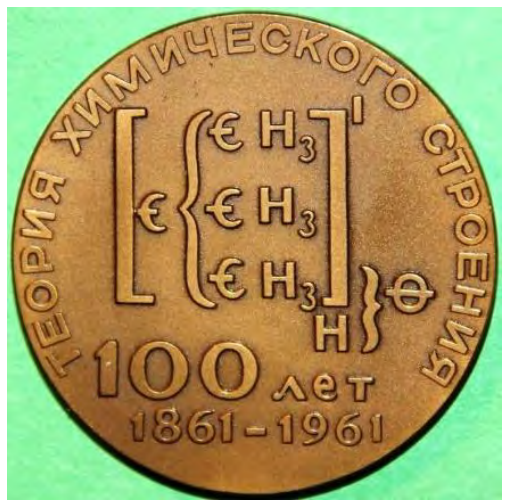

Fig. 34. Butlerov medal (reverse)

Ernst Jünger (1895-1998) - German novelist and essayist, German soldier, an ardent militarist who was one of the most complex and contradictory figures in 20th-century German literature. He became publicly known for his World War I memoir "Storm of Steel". After being discharged from the army in 1923, Jünger studied zoology and botany at the Universities of Leipzig and Naples. He became a well-known entomologist. In Germany, an important entomological prize is named after him: the Ernst-Jünger-Preis für

\footnotetext{
25 Мычко Д.И. Александр Михайлович Бутлеров. Хімія: праблемы выкладання. 2008. № 6. C. $12-18$.
} 
Entomologie. Jünger served as an army staff officer in Paris during World War II, but by 1943 he had turned decisively against Nazi totalitarianism and its goal of world conquest.

Medal dedicated to the 70th anniversary of Ernst Junger $(86.5 \mathrm{~mm}$, bronze, author - R. Triebel, Germany, 1970). Obverse (fig. 35) - portrait of Jünger, and facsimile under the portrait. Reverse (fig. 36): in the center - a beetle (A sacred scarab), along the edge - an inscription: "MCMLXX" (1970). The image of Scarab probably symbolizes not only Jünger's involvement in entomology, but also a symbol of the creative power of the Sun, Junger's creative activity over a long life.

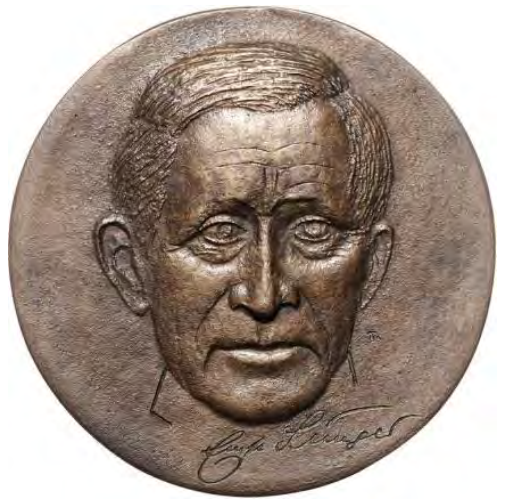

Fig. 35. Jünger medal (obverse)

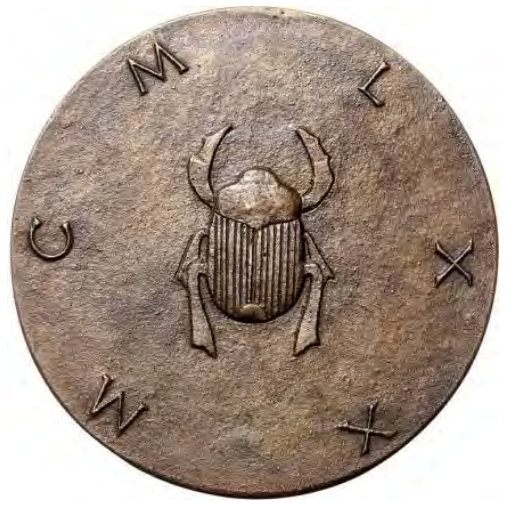

Fig. 36. Jünger medal (reverse)

Another famous writer was an entomologist also. It's about Vladimir Vladimirovich Nabokov (1899-1977). He was a Russian and American novelist, poet, translator and, as we mentioned, entomologist. Nabokov's "Lolita" (1955) was ranked fourth in the list of the Modern Library 100 Best Novels in 2007, he was a finalist for the National Book Award for Fiction seven times.

In USA Nabokov began volunteer work as an entomologist at the American Museum of Natural History. In 1941 he became the resident lecturer in comparative literature in Wellesley College and free time devoted to lepidoptery. Nabokov was the de facto curator of lepidoptery at Harvard University's Museum of Comparative Zoology. During the 1940s, as a research fellow in zoology, he was responsible for organizing the butterfly collection of the Museum of Comparative Zoology at Harvard University. He described the Karner blue (Plebejus melissa samuelis). The genus Nabokovia was named after him. About 4,300 specimens from his collection was given to the Lausanne's Museum of Zoology in Switzerland.

A famous Russian-American sculptor A. Shagin created a plaque (70x70 mm, cast bronze, USA) in honor of Nabokov (fig. 37). 


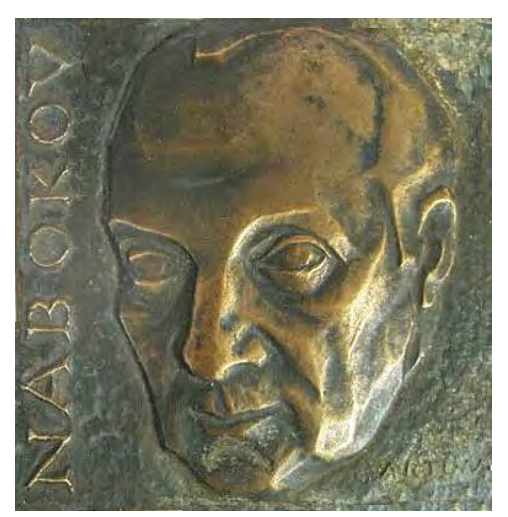

Fig. 37. Nabokov plaque

\section{CONCLUSIONS}

The Special Historical Discipline - medallic art, represented by table art medals of France, Sweden, Czech Republic, Italy, Finland, USA, Germany, former USSR, became the historical material source (or a manual) for studying the history of entomology. A number of medals presented and put into scientific circulation for the first time. Of particular interest were medals showing portraits of entomologists and objects of their research. A separate section is dedicated to doctors, biologists and entomologists, whose research has successfully carried out the fight against dangerous diseases such as yellow fever, malaria, and sleeping sickness. Entomology enthusiasm did not pass many outstanding people, primarily writers, to whom a separate section is devoted.

\section{SUMMARY}

The Special Historical Discipline - medallic art, represented by table art medals of France, Sweden, Czech Republic, Italy, Finland, USA, Germany, former USSR, became the historical material source (or a manual) for studying the history of entomology. A number of medals presented and put into scientific circulation for the first time. Of particular interest were medals showing portraits of entomologists and objects of their research: P.A. Latreille, Carl Fredrik Fallén, Jean-Henri Casimir Fabre, Antonin Fleischer, Mario Bezzi, Harry Federley, Esko Suomalainen, and Germaine Cousin. A separate section is dedicated to doctors, biologists and entomologists, whose research has successfully carried out the fight against dangerous diseases such as yellow fever, malaria, and sleeping sickness: Louis-Daniel Beauperthuy, Walter Reed, William Crawford Gorgas, etc. Entomology enthusiasm did not pass many outstanding people, primarily writers, to whom a separate section is devoted: Jean Charles Emmanuel Nodier, Sergey Timofeyevich Aksakov, Alexander Mikhaylovich Butlerov, Ernst Junger, and Vladimir Vladimirovich Nabokov. 


\section{REFERENCES}

1. Спеціальні історичні дисципліни: довідник : навч. посіб. для студ. вищ. навч. закл. / І.Н. Войцехівська (кер. авт. кол.) та ін. Київ : Либідь, $2008.520 \mathrm{c}$.

2. Барштейн В.Ю. Новая функция специальных исторических дисциплин. Материаль международной заочной научной конференции «Исторические исследования». Уфа, 2012. С. 76-79.

3. Essig E.O. A History of Entomology. Hafner Publishing Company, 1965. 1029 p.

4. Smith E.H., Kennedy G.G. Chapter 119 - History of Entomology. In: Encyclopedia of Insects (Second Edition). 2009. P. 449-458.

5. Smith M.E. Philatelic Lepidoptera: 1954-1957. The Lepidopterists' News. 1957. № 11 (6): 221-224.

6. Hessel S.A. A Taxonomic list of philatelic Lepidoptera. Journal of the Lepidopterists' Society.1968. 22 (4): 241-252.

7. Hamel D.R. Insects on stamps. American Entomologist. Winter 1990. P. 273-281.

8. Pruess K.P. Postage Stamps Showing Bees and Hives. Bee World. 2015. P. 53-56.

9. Gomez B., Junghans C. Los alacranes (Arachnida: Scorpionida) en la filatelia. Scorpions (Arachnida: Scorpionida) in postal stamps. Dugesiana. 2016. 23 (1): 37-43.

10. Kabourek K. Beetles on stamps. Ethnoentomology. 2017. 1: 52-72.

11. Lhoste J. Les insectes et les medailles de la Monnaie de Paris. Insectes. 1988. 69 (2): 16-19.

12. Блюм Я., Барштейн В. Ювілей Чарльза Дарвіна в медальєрному мистецтві. Вісник Національної академї наук Украӥни. 2009. № 2. C. $51-55$.

13. Барштейн В.Ю. Карл Лінней, його внесок у біологічну науку в медальєрному мистецтві. Наукові звписки Тернопільського національного педагогічного університету імені Володимира Гнатюка. Серія: Біологія. 2011. № 3 (48). C. 143-150.

14. Dupuis C. Pierre Andre Latreille (1762-1833): The Foremost Entomologist of his Time. Annual Review of Entomology. 1974. 19 (1): 1-14. DOI: 10.1146/annurev.en.19.010174.000245

15. Гиляров М.С. Жан Анри Фабр. К 150 -летию со дня рождения. Энтомологическое обозрение. 1974. Т. 53. № 1.

16. Koleška Zdeněk. "Fleischer Antonín". Biografický slovník. 2014. 17: $257-258$.

17. Goldschmidt R.B. Harry Federley: 1879-1951. Science. 1952. 115: 561-562. DOI: 10.1126/science.115.2995.561-a 
18. Mikkola Kauri. Biography of Prof. Esko Suomalainen, Honorary member of SEL. Notalepid. 1987. 10 (2): 113-114.

19. Godoy G.A., Tarradath E. Short biography of Louis Daniel Beauperthuy (1807-71): pioneer of microbiology and medical science in Venezuela. Journal of Medical Biography. 2010. 18: 38-40. DOI: 10.1258/ jmb.2009.009095

20. Cashman T.M. William Crawford Gorgas. He Set the Standard of Military Preventive Medicine. Hawaii Medical Journal. 1998. 57: 377-380.

21. Craddock W.L. The Achievements of William Crawford Gorgas. Military Medicine. 1997. 162 (5): 325-327.

22. Neghme A. An Appraisal of Giovan Battista Grassi: His Work in Biology and Parasitology. Experimental Parasitology. 1964. 15: 260-278.

23. Emile Roubaud (1882-1962). URL: http://www.pasteur.fr/infosci/ archives/f-bio.html

24. Loving M. Charles Nodier: The Romantic Librarian. Libraries \& Culture. Vol. 38. №. 2. P. 166-181.

25. Мычко Д.И. Александр Михайлович Бутлеров. Хімія: праблемь выкладання. 2008. № 6. С. 12-18.

Information about author: Barshteyn V. Yu., Candidate of Technical Sciences, Head of the Laboratory for Extraction of Vegetable Raw Materials and Bioconversion Institute of Food Biotechnology and Genomics of the National Academy of Sciences of Ukraine 2a, Osipovskogo str., Kyiv, 04123, Ukraine 